\title{
Perancangan dan Pembuatan Aplikasi Permainan Petualangan "Gatotkaca Dalam Perang Baratayuda"
}

\author{
Hermawan Andika, S.Kom., M.Kom. \\ Jurusan Teknik Informatika \\ Institut Informatika Indonesia \\ Jl. Raya Sukomanunggal Jaya 3, \\ Surabaya \\ andi@ikado.ac.id
}

\author{
Anggya N.D. Soetarmono, S.Kom. \\ Jurusan Teknik Informatika \\ Institut Informatika Indonesia \\ Jl. Raya Sukomanunggal Jaya 3, \\ Surabaya \\ anggya@ikado.ac.id
}

\begin{abstract}
ABSTRAK
Gatotkaca merupakan salah satu tokoh pewayangan yang sangat populer di Indonesia. Game atau yang biasa disebut permainan merupakan aktivitas terstruktur atau semi terstruktur yang biasanya bertujuan untuk menghibur. Dengan memanfaatkan media permainan untuk mengenalkan sejarah pewayangan, menjadi tujuan utama penulis dalam melestarikan budaya Indonesia. Pengembangan permainan ini akan menggunakan framework starling, dengan hasil berupa aplikasi yang dapat dimainkan melalui web dan mobile phone (android \& i-phone). Aplikasi permainan ini merupakan penggabungan antara visual novel game dan action game. Melalui visual novel game pemain dapat mengenal sejarah gatotkaca dalam perang Baratayuda. Sedangkan dari action game pemain dihibur dengan beberapa pola permain yang beragam.
\end{abstract}

Kata Kunci: Game, Gatotkaca, Framework Starling.

\section{PENDAHULUAN}

Perkembangan ilmu pengetahuan dan teknologi mendorong proses pembelajaran untuk menarik sebagai upaya untuk peningkatan kualitas pendidikan. Inovasi dan metode pengajaran yang baru dan tepat akan membantu proses pemahaman pengguna teknologi sehingga dapat mengaplikasikan ilmu yang diperoleh dalam kehidupan seharihari. Salah satu cara untuk mendorong tercapainya pembelajaran yang efektif, digunakan alat bantu belajar atau yang biasa disebut media.

Salah satu media yang dapat digunakan dalam pembelajaran adalah aplikasi game atau permainan. Game merupakan aktivitas terstruktur atau semi terstruktur yang biasanya bertujuan untuk hiburan dan kadang dapat digunakan sebagai sarana 
pendidikan. Karakterisitik game yang menyenangkan dan memotivasi membuat aktivitas ini digemari oleh banyak orang.

Game dapat mengajarkan banyak keterampilan dan dapat dijadikan sebagai salah satu alternatif pendidikan. Bermain game merupakan sebuah literacy baru dalam pendidikan.

Permainan “Gatotkaca Dalam Perang Baratayuda” adalah permainan petualangan bertema pewayangan dimana pemain harus menyelesaikan misinya tiap level. Dalam permainan “Gatotkaca Dalam Perang Baratayuda” terdapat unsur cerita budaya sehingga pemain dapat memahami alur ceritanya. Dengan latar belakang tersebut, maka penulis tertarik untuk mendalami pembuatan permainan android dan diwujudkan dengan perancangan dan pembuatan permainan petualangan “Gatotkaca Dalam Perang Baratayuda”.

Dengan latar belakang tersebut, maka penulis tertarik untuk mendalami pembuatan permainan android dan diwujudkan dengan perancangan dan pembuatan permainan petualangan “Gatotkaca Dalam Perang Baratayuda”.

\section{METODOLOGI PENELITIAN}

\section{A. Android}

Android adalah sistem operasi (OS) untuk telepon seluler yang berbasis Linux. Android menyediakan platform terbuka bagi para pengembang buat menciptakan aplikasi mereka sendiri untuk digunakan oleh bermacam peranti bergerak”. Awalnya, Google Inc. membeli Android Inc., pendatang baru yang membuat peranti lunak untuk ponsel. Kemudian untuk mengembangkan Android, dibentuklah Open Handset Alliance, konsorsium dari 34 perusahaan peranti keras, peranti lunak, dan telekomunikasi, termasuk Google, HTC, Intel, Motorola, Qualcomm, T-Mobile, dan Nvidia. Android begitu pesat perkembangannya di era saat ini karena Android menyediakan platform terbuka (Open source) bagi para pengembang untuk menciptakan aplikasi mereka sendiri.

\section{B. Adobe Flash Builder}

Adobe Flash Builder - sebuah lingkungan pengembangan terintegrasi untuk menciptakan cross-platform aplikasi Internet kaya. Menggunakan Flash Builder, membuat aplikasi yang menggunakan infrastruktur Adobe Flex, MXML, Adobe Flash 
Player, Adobe AIR, ActionScript 3.0, Adobe LiveCycle ES Layanan Data komponen dan Adobe Flex Charting. Juga termasuk alat untuk pengujian, debugging dan profiling, yang dicapai melalui peningkatan produktivitas dan efisiensi. Adobe Flash Builder memiliki antarmuka multibahasa.

\section{Starling}

Starling adalah ActionScript 3 library untuk Adobe Flash. Ini dapat membuat kembali tambilan Adobe Flash pada GPU dan memberikan performa yang luar biasa bahkan pada platform Mobile, seperti iOS dan Android .

Selain bahasa, starling ini tidak memerlukan pengetahuan tentang dasar Flash (ActionScript 3). starling memulai penjelasan dari awal, dimulai dengan cara mengatur proyek, kemudian menjelaskan bagaimana pohon display dan sistem event bekerja, dan menunjukkan kepada anda bagaimana untuk mencapai tugas-tugas tertentu, seperti menghidupkan benda.

\section{HASIL PEMBAHASAN}

Beradasarkan hasil peneilitian yang telah dilakukan, maka didapatkan hasil akhir sebuah permainan “Gatotkaca Dalam Perang Baratayuda”.

\section{A. Elemen Permainan "Gatotkaca Dalam Perang Baratayuda"}

- Arena Permainan

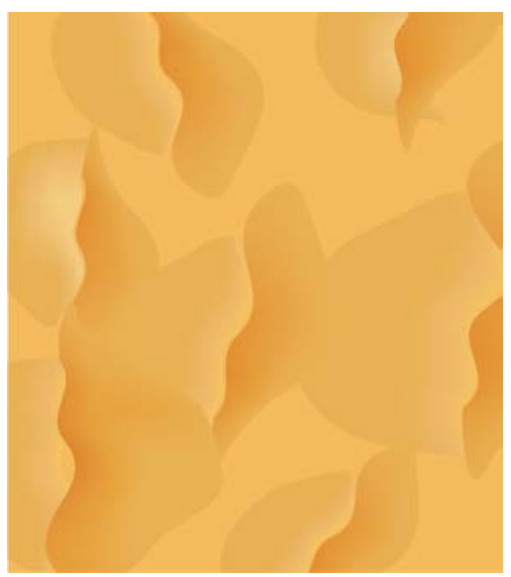


- Pemain (Karakter Gatotkaca)

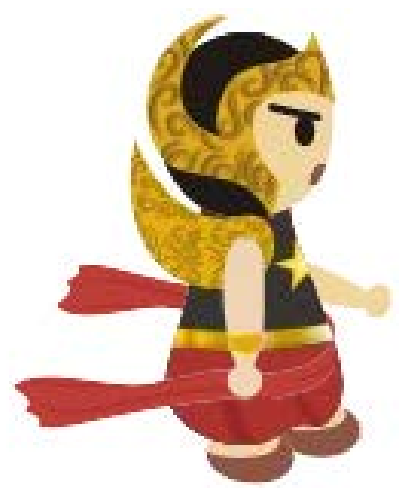

- Karakter Pendukung Permainan

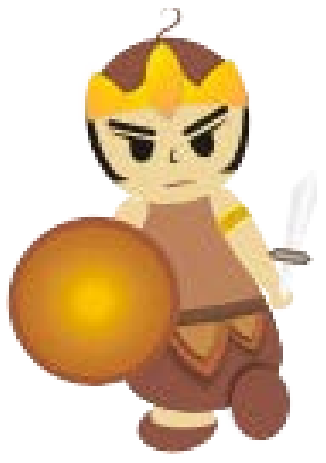

- Rakyat Jelata

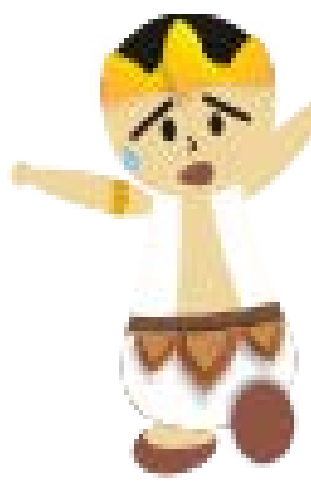

- Bos Pada Level Akhir

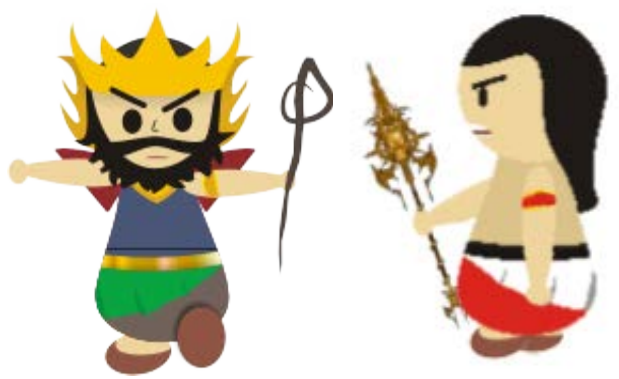

\section{B. Menu Utama}

Menu utama adalah menu awal dari permainan ini. Didalam menu ini terdapat 3 buah tombol yaitu tombol Main, Cara Bermain, dan Persembahan yang mengarah ke menu yang lainnya. Bila pemain menekan tombol Main, maka pemain akan disambungkan ke menu pemilihan level. Bila pemain menekan tombol Cara Bermain, maka pemain akan disambungkan dengan menu Cara Bermain. Bila pemain menekan tombol Persembahan, maka akan disambungkan dengan menu Credit.

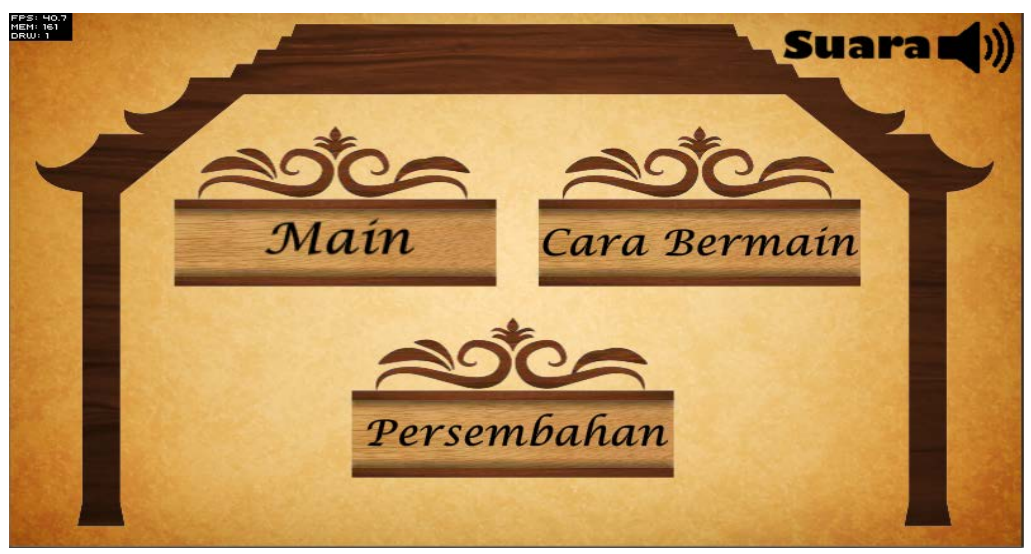




\section{Permainan Level 1}

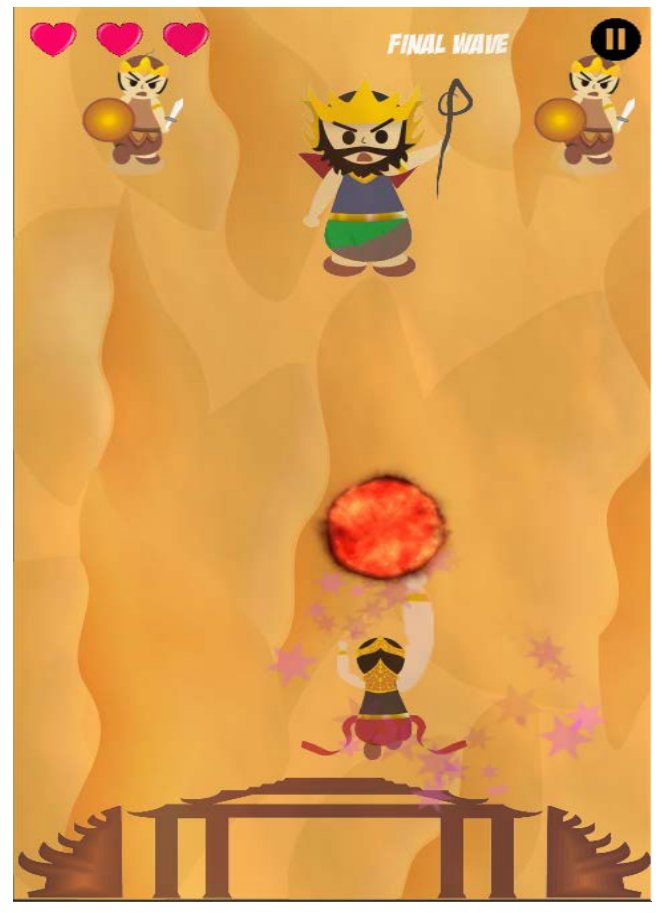

Permainan level 1 menggunakan fitur touch screen untuk menyerang musuh yang berjalan dan menggagalkan serangan bola api dari bos terakhir. 3 tipe karakter berjalan secara vertikal dari atas ke bawah, karakter tersebut bersenjatakan pedang dan gada serta terdapat rakyat jelata. Posisi awal keluar dan kecepatan karakter tersebut akan diacak. Kemudian pemain menekan musuh yang membawa senjata, sehingga Gatotkaca akan menuju posisi karakter dan memukulnya. Jika pemain menekan rakyat jelata, maka nyawa pemain akan berkurang sebanyak 1 poin.

Jika rakyat jelata melewati Gatotkaca maka nyawa pemain tidak akan berkurang, namun ketika musuh yang membawa senjata melewati Gatotkaca maka akan mengurangi nyawa pemain.

Setelah semua musuh berhasil dikalahkan maka bos dari level 1 akan keluar dan menyerang pemain menggunakan bola api. Untuk mengalahkan bos pada level 1, pemain harus mengembalikan serangan bola api dengan cara menekan bola api yang menuju kearah Gatotkaca. Setelah bola api tersebut ditekan, maka bola api itu akan kembali ke arah bos dan mengenainya serta mengurangi ketahanan dari bos itu sendiri. Bos akan bergerak secara acak kekiri atau kekanan setelah menyerang Gatotkaca. Pergerakan bos akan menuju ke titik - titik tertentu pada sumbu Y (vertikal), dimana tiap titik akan berjarak sebanyak 100 pixel terhadap arena permainan. Ketika Bos berada di titik pada arena permainan tertentu pergerakan bos akan terhenti dan bos akan 
menyerang menggunakan bola api. Setelah bos menyerang dengan bola api, maka bos akan berpindah ke titik lainnya pada arena permainan. Jika pemain tidak menekan bola api dari bos, maka nyawa pemain akan berkurang sebanyak 1 poin.

\section{Permainan Level 2}

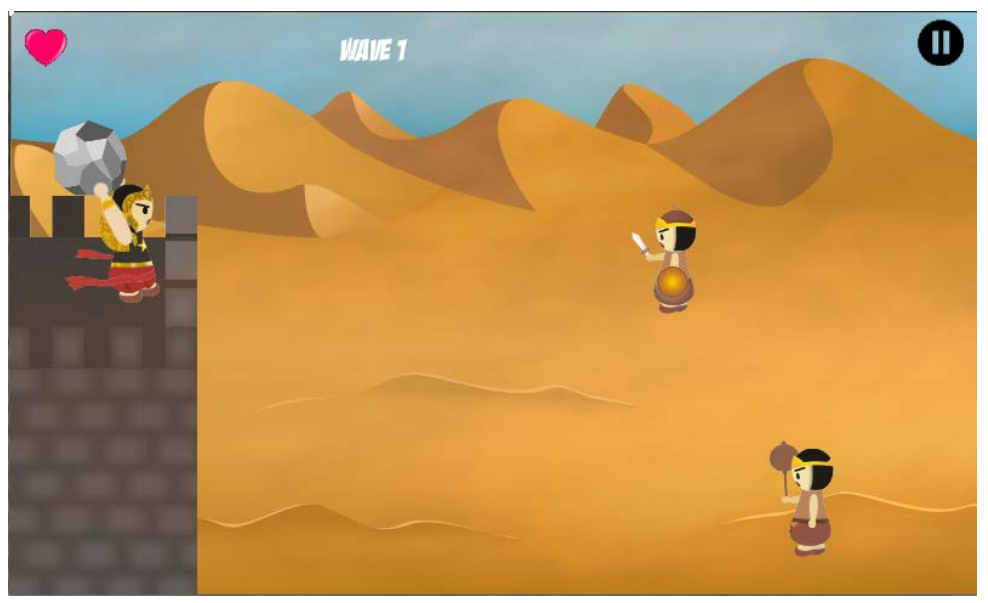

Permainan level 2 ini menggunakan fitur swipe terhadap batu yang dipegang oleh karakter Gatotkaca yang berdiri di atas menara dan pemain harus melindungi menara tersebut dari musuh. Terdapat 3 tipe karakter yang bergerak secara horizontal dari kanan ke kiri, musuh bersenjatakan pedang dan gada serta terdapat rakyat jelata.

Posisi awal keluar dan kecepatan karakter akan diacak. Batu yang dipegang oleh Gatotkaca dapat ditarik (swipe) untuk melempar batu. Untuk membuat lemparan batu semakin cepat maka pemain dapat menarik batu yang dipegang oleh Gatotkaca lebih jauh kebelakang yang diibaratkan seperti ketapel.

Jika batu yang dilempar Gatotkaca tepat mengenai salah satu musuh yang membawa senjata, maka musuh tersebut akan menghilang. Setelah semua musuh berhasil dikalahkan, maka bos dari level 2 akan muncul. Bos akan menyerang dan mengurangi nyawa pemain jika pemain tidak menggagalkan serangannya. Untuk menggagalkan serangan bos tersebut, pemain harus melempar batu kearah bos. Setelah pemain berhasil menggagalkan serangan bos level 2, maka bos tersebut akan bergerak menuju titik - titik tertentu pada sumbu X (horisontal) dan sumbu Y (vertikal), dimana setiap titik pada arena permainan berjarak 50 pixel terhadap arena permainan. 


\section{E. Permainan Level 3}

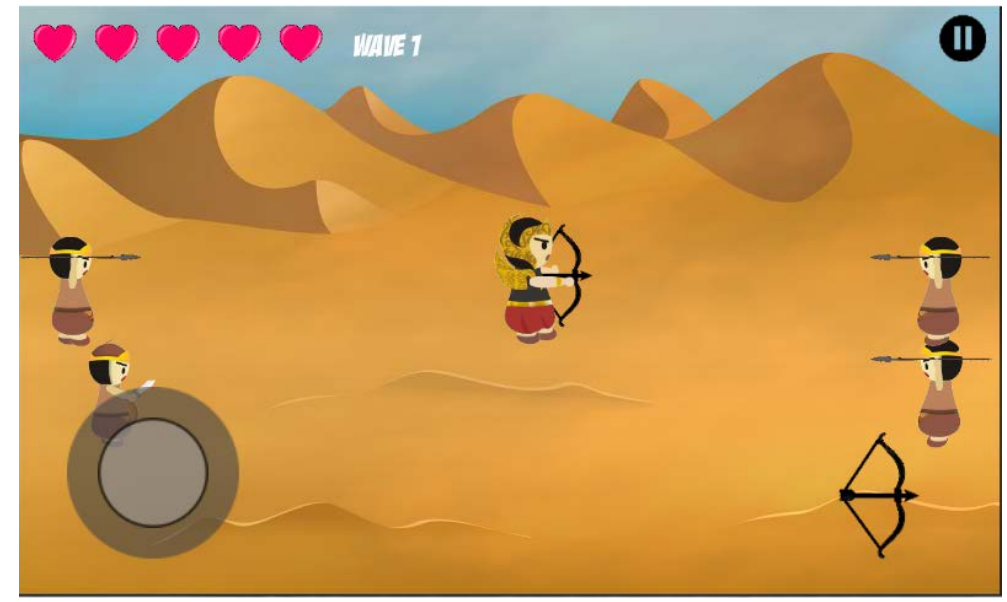

Pada permainan level 3 pemain akan diberi kontrol untuk menggerakan gatotkaca kesegala arah serta kontrol untuk dapat menembakkan panah. Terdapat 2 tipe musuh, musuh yang bergerak kearah Gatotkaca yaitu musuh pedang yang menyerang dari jarak dekat dan musuh tombak yang menyerang dari jarak jauh. Posisi awal keluar dan kecepatan tiap karakter akan diacak.

Ketika serangan musuh berhasil mengenai Gatotkaca, maka nyawa pemain akan berkurang sebanyak 1 poin. Setelah semua pasukan berhasil dikalahkan oleh pemain, maka bos dari level 3 akan keluar dan bergerak menyerang kearah Gatotkaca. Pergerakan bos akan selalu mengikuti Gatotkaca. Ketika bos level 3 sudah sejajar dengan Gatotkaca, maka bos level 3 akan mengeluarkan tombak. Serangan bos berupa serangan jarak jauh yang dapat dihindari oleh pemain. Bos pada level ini memiliki ketahanan yang lebih besar daripada musuh biasa.

\section{KESIMPULAN}

Terdapat beberapa kesimpulan yang dapat diambil dari proses pembuatan permainan petualangan "Gatotkaca Dalam Perang Baratayuda”. Kesimpulan yang dapat diambil antara lain:

- Agar permainan petualangan "Gatotkaca Dalam Perang Baratayuda" dapat berjalan pada sistem operasi android maka dibutuhkan framework Starling dengan bantuan program Adobe Flash Builder. 
- Dari kuisioner yang didapat dapat dinyatakan bahwa pemain puas memainkan permainan petualangan "Gatotkaca Dalam Perang Baratayuda” dikarenakan terdapat pola permainan yang berbeda ditiap level permainan.

\section{REFERENSI}

[1] Ed Burnette., Hello Android 2nd Edition, USA, 2012.

[2] H, Nazaruddin Safaat, Android Pemrograman Aplikasi Mobile Smartphone dan Tablet PC Berbasis Android, Edisi Revisi, Informatika, Bandung. 2012.

[3] Mas Patikrajadewaku, BARATAYUDA Perang menuai karma, Bandung, 2010.

[4] Michael Siregar I., Yusuf R., Siendow W., Wino W W., Mengembangkan Aplikasi Enterprise Berbasis Android, Gava Media, Yogyakarta, 2010.

[5] Mulyadi, S.T., Membuat Aplikasi Untuk Android, Multimedia Center Publishing,

[6] Yogyakarta, 2010.

[7] Pitoyo Amrih, ANTAREJA ANTASENA JALAN KEMATIAN PARA KSATRIA, Pinus Publiser, Yogyakarta, 2006

[8] Reito Meiler., Profesional Android Application Development, Wiley Publishing, Canada, 2009.

[9] Suhendar A., Visual Modelling Menggunakan UML dan Rational Rose, Informatika Bandung, Bandung, 2002.

[10] Suprianto, Dodit dan Rini Agustina, S.Kom, M,Pd, PEMROGRAMAN APLIKASI ANDROID, MediaKom, Yogyakarta, 2012 